\title{
Some Remarks on the Nineteenth Century Studies of the Euthyphro in Poland*
}

TOMASZ MRÓZ / Zielona Góra /

The works of Polish philosophers, historians and classicists on the Euthyphro in the $19^{\text {th }}$ century developed independently of any translations of the dialogue, even though two Polish translations of the dialogue were published (Platon 1858 and 1881) in the century ${ }^{1}$. The purpose of this paper is to provide evidence for a twofold interest that Polish readers had for Plato's Euthyphro in the second half of the $19^{\text {th }}$ century. Firstly, Catholic thinkers brought up the ethical issues of the dialogue and supported the revival of the Scholasticism, confirming, at the same time, the vitality of Plato's thought. Secondly, the text of Plato's opusculum was a convenient didactic material for various teachers of

* This study was financed from the funds for scholarly research in the years 2008-2010 as a project no. NN 101 116435. I would like to thank Una Maclean-Hanćkowiak for proof-reading the English text.

1 The Euthyphro inspired also an eminent Polish translator of Plato’s dialogues, Władysław Witwicki, who is often referred to as the 'Polish Schleiermacher'. As a gymnasium student, he was attracted to the problems touched upon in the dialogue, where he found important answers to his youthful ethical dilemmas that could not be solved satisfactorily by his catechism teacher (Jeżewska 1957: 5). 
the Greek language: while the Euthyphro gave them the opportunity to raise ethical and logical issues, they also taught philosophy on the basis of this dialogue.

As already mentioned, the studies focusing on the Euthyphro, as well as these devoted to Plato in general, manifested two main tendencies. On the one hand, they stressed various contemporary issues, especially the decline of religion and morals, and, on the other, they were historical and philosophical studies. These two tendencies frequently co-existed, e.g. in the studies published in the annual reports of classical gymnasiums. The following overview, apart from its informative purpose, aims to examine the reasons which made the various thinkers, teachers, philosophers and historians read and comment on the Euthyphro.

One of the works that focused on the contemporary meaning of the Euthyphro was entitled "Euthyphro", the First Platonic Dialogue, Analyzed and Estimated According to the New Intellectual Movement. The work was published in five parts and written by an author who hid themselves behind the pseudonym "C."2 In this text, along with the passages devoted explicitly to the substance of the Euthyphro, the author made various remarks concerning the future of Poland and the Catholic Church, the decline of values, the critique of the socialist and individualistic movements etc. Furthermore, the author made several critical references to sophistry and German philosophy, especially Hegelianism, which he considered to be a serious obstacle on the way to the Kingdom of God (Adamski 1883/1884: 4618).

Let us now pass on to the text itself. At the very beginning one can find a declaration of the necessity to revive philosophy in order to bring about the victory of the only true religion, i.e. Catholicism. The need of becoming reacquainted with Greek philosophy was justified by Adamski (1883/1884: 4577) in the following way: "since reason has to precede faith and philosophy has to pave the way for the revealed religion, and since we have to turn back to where we came from in our modern civilization, we also have to turn to the philosophy, that preceded the birth of the Gospel, which is Greek philosophy." The value of Greek philosophy was twofold. Firstly, it provided the foundation for the structure of Catholic theology. Adamski did not need to convince the reader of the magnificence of the latter. Secondly, no faith can dispense with reason, and, consequently, it was Christianity together with philosophy that was to create the future of Christianity. However, Adamski had little respect for the philosophy of the $19^{\text {th }}$ century, because of its absolutist trends, its pluralism and ethical relativism. The clash between the opposing philosophical schools and positions was regarded by Adamski as the weak point of contemporary philosophy.

Following the introduction, Adamski suggested a cure for this sad state of contemporary thought, i.e. a return to the principles of reason and their roots in Greek philosophy.

2 The most probable identity of the „C.” is Jan Adamski (1841-1918), who after joining the order of the Carmelites received the lay name: Celestinus. This would explain the initial. He was a Catholic writer, involved in various social and national matters. His philosophical education was generally scholastic and Thomistic, as he received it in the convents of the Jesuits in Galizia. His intellectual interests were, however, much broader than merely scholastic. His works were devoted to a. o. the philosophy of Polish messianism. 
He argued that this had been insufficiently acknowledged by his contemporaries who were unaware of its full picture and, thus, of the roots of European rationalism. "Modern philosophy can never turn its back on Aristotle and Plato, the two most outstanding lights shining from the remotest antiquity" (Adamski 1883/1884: 4585). Adamski ascribed to them the elaboration of the two opposing methods: deduction and induction. He considered Aristotle to have sufficiently applied both of them, whereas induction, he claimed, had Platonic origins. It was the method of induction that Adamski (1883/1884: 4585) recognized as the best one: "it can lead us into the invisible spiritual world, by investigating its essence from its appearance; it can uncover the mysteries of the Divinity itself, leading to the recognition of Its essence from the created beings which are Its work." Furthermore, Adamski (1883/1884: 4586) pointed out that the instinct, feeling, and intuition of the truth are connected to the inductive method: "This gift of intuition is an inter-

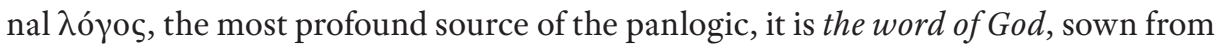
eternity [...] as St. Augustine expresses it in his profound words, the internal Christ and our incessant teacher." Through the logos, then, innate to human nature, the rationality of human nature is identical to its Christian character. Thus, having acknowledged induction and intuition as sufficient methods for recognizing the highest truths, Adamski (1883/1884: 4586) justified the title and subject of his work: "this is why in this study I refer to Plato, the incomparable master, who prepared the way for the Divine master, Jesus Christ." Hence, his reason for choosing the Euthyphro was that it was an example of applying the inductive method.

In the next passages, Adamski attempted to summarize the dialogue. Instead of using the Greek names of the gods $(8 \mathrm{~b})$, he quoted Jove and Saturn. While reconstructing the substance and the main issues of the dialogue, he added his critical remarks on polytheism and pantheism. When Socrates proved that Euthypro's definition of piety, as that which pleases the gods, is wrong, because there is no unity in this issue among the gods, Adamski (1883/1884: 4594) wrote: "Let us consider the alogic consequences of polytheism and, thereby, of pantheism. If everything is divine, then the world is composed of opposite things. If we suppress the difference between them, then it will appear as full of contradictions. Thus, it is logic itself that leads us to one God. The same logic leads us also to the personal God."

Having given the overview of the dialogue, Adamski draws his conclusions. First of all, Socrates is a philosopher that is aware of the fact that all knowledge needs to be founded on a rigid and eternal truth, for without it, as Adamski argues, the social order will be destroyed. The philosophical and theological knowledge which was founded on the eternal truth had been elaborated in the Middle Ages. It was impossible in the times before Christianity: "and this lets us understand why Leo XIII announced the return of the theological knowledge towards scholasticism, the only ark of Catholic reason, saved in the deluge of subjective notions, which has flooded the modern world" (Adamski 1883/1884: 4605). Though, as Adamski remarked, neither Socrates nor Plato discovered the existence of a personal God, they came to a recognition of ideas which cannot be anything but the perfect, original pattern of the created world. And this pattern is equal 
to the essence and existence of God, being at the same time the criterion of truth. This is how, according to Adamski, Plato approximated the opening words of the Gospel of John.

Applying his conclusions to the trail of Socrates, Adamski wrote that Plato's teacher merely opposed the belief of polytheism with "pure reason". In monotheistic Christian thought, Adamski argued, the definition of piety, as that which pleases God, is maintainable. Being an opponent of any revolutionary movements, Adamski appreciated the attitude of Socrates, who was a total enemy of the official religion, but whose radicalism was limited to the theoretical sphere only. It was in pure theory that he was an adherent of monotheism. In practice, however, he did not intend to overthrow the religious status quo. He refrained from the latter, because it was "so fatal in its results, because it was unreasonable and provided evidence of intellectual immaturity" (Adamski 1883/1884: 4606). Socrates recognized the power of religious institutions and he knew that even a false religion is better than atheism. A false religion may hold people in a vicious circle and hamper progress, but as a religion, it always exerts some beneficial influence that no atheism can offer.

After further exposition of the Christian view of God, Adamski returned to the Euthyphro. Socratic induction was described as a method of discovering the world of ideas, which is, after all, a method "guiding the spirit through the visible shapes to the highest glittering lights of the invisible world and to the sun of the wisdom itself" (Adamski 1883/1884: 4618). About Socrates and Plato Adamski (1883/1884: 4618) wrote: "With his method Socrates testified to the word from the eternity, residing in the human spirit, and being the source of all knowledge, all morals and human perfection. In this way, Plato, who illustrated and perfected the method of his master in his admirable dialogues, approached the Divine kingdom, which descended on the earth with the word which became flesh and dwelt among people to transform the human race into the temple of the God, and therefore this philosophy is a preface to the Gospel".

At the end of his paper Adamski (1883/1884: 4618) expressed his view concerning the part that Plato's legacy should play in modern times: "These dialogues of Plato show us how our social meetings, the common conversations and the feasts have to become for us the school of wisdom together with all the charm of life, free from scholastic discipline; how the conversations are to ennoble us, and how the feasts of the mortals are to be turned into the feasts of the gods, an example of which was given by Plato in his Symposium". The last verses of Adamski's paper expressed views closer to those of humanism than to scholasticism.

Adamski's text on the Euthyphro is in some respects surprising. A Christian author choosing the Euthyphro for his subject would be expected to focus on its main point, i.e. the piety. In the work examined, however, the relation between faith and philosophy became the most important issue. What Adamski called the inductive method was a kind of philosophical investigation supported with intuition and that lead from the Creation to the Creator. This method was exemplified by the Socratic-Platonic philosophy. The right understanding of this method, however, was possible only owing to the Christian tradition. Both Plato and Christian thought practice the inductive method, which "consists 
in the law of likeness and analogy, by which the real being is linked with the ideal one, whereas the created things are linked with the Creator" (Adamski 1883/1884: 4619). The Euthyphro was also to prove that philosophy does not have to be incomprehensible and exclusive, as Adamski viewed Hegelianism. He wrote: "I have shown how philosophy must become popular and accessible to everyone with a simplicity that philosophy has lost long time ago" (Adamski 1883/1884: 4619). Contrary to what Plato could have imagined, the Euthyphro became a pretext for discussing the complicated relations between ancient culture and Christianity. The Euthyphro was shown to support the Neo-Scholastic movement.

Another Catholic thinker who devoted several pages to the Euthyphro in his extensive, though unfinished, History of Greek Philosophy from Thales to the Death of Aristotle, was Stefan Pawlicki ${ }^{3}$. It is significant that his discussion of the Euthyphro was placed in the chapter devoted to Socrates. One might conclude that Pawlicki considered this dialogue to be a credible source for reconstructing the character of Socrates as a philosopher. Such a conclusion is indeed right. For Pawlicki, the Euthyphro was the best example illustrating the essence of the Socratic method. He wrote about it: "It was known also as an irony

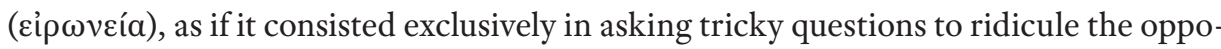
nent. The Sophists considered themselves to be wise men. By means of his questions, Socrates uncovered the emptiness of their wisdom. The situation became comic through the antithesis between the pretense of wisdom to the actual nonsense. At the same time, it was also tragic when moral perversity was shown to hide behind the alleged wisdom" (Pawlicki 1890: 363). In this respect the Euthyphro was very helpful for Pawlicki's argument. He concluded his three page summary of the dialogue with the following statement: "A splendid example of Socratic irony as well as of the art of discovering definitions" (Pawlicki 1890: 366, n. 1). At the same time he encouraged the reader to make himself acquainted with the whole of the dialogue. According to Pawlicki the Euthyphro was not a dialogue contributing anything substantial to our knowledge of Platonism. He made use of this dialogue as well as others, and occasionally of the works of Xenophon, to indicate the essential components of the philosophy of Socrates, including the method of irony, the 'purging of minds' and 'moral regeneration'. One important feature of Socrates' philosophizing was however recognized as being absent from the Euthyphro: "the inven-

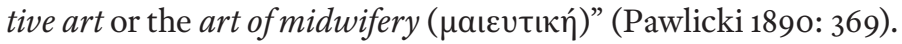

Pawlicki regarded the early dialogues, including the Euthyphro, as historical sources providing us with knowledge of Socrates. His argument had it that: “In Xenophon's Memorabilia Socrates is a good-natured and kind-hearted townsman who is guided by practical reason in moral questions, and who carefully avoids all other, especially religious and metaphysical issues. In Plato, he is a daring and profound thinker, who solves the most radical and convoluted metaphysical and theological problems with exceptional

\footnotetext{
3 S. Pawlicki (1839-1915) was born in Gdańsk (Danzig) and gained Ph.D. in Wrocław (Breslau). His thesis concerned the philosophy of A. Schopenhauer. After being ordained and having lectured in Rome, he came to Kraków and till his last days lectured in theology and philosophy at the Jagiellonian University.
} 
absoluteness, often showing disregard for the tradition and beliefs of his own nation. In a word, Plato's Socrates is as noble as Xenophon's is ordinary and cheap" (Pawlicki 1890: 375). Settling the dispute between the two images of Socrates, Pawlicki favored Plato's Socrates as true to the historical Socrates. He refused to acknowledge any value of Xenophon's testimony: "Such a Socrates would never have been poisoned by the Athenians" (Pawlicki 1890: 375). It was quite obvious to him that Plato was the one who captured the authentic image of Socrates: "Plato is a great devotee of the truth; the characters of his dialogues are as real as portraits can be. A photographic exactness should not be expected of a portrait" (Pawlicki 1890: 375). Furthermore, Xenophon was not a philosopher, and in all probability he did not even think highly of philosophy. This was yet another reason to assume the priority of Plato's testimony.

From Pawlicki's Catholic point of view, an important question raised in the Euthyphro was the issue of the daimonion. Nevertheless, when discussing the issue Pawlicki did not quote the Euthyphro. Rather, he merely stated that some kind of internal voice must have appeared in Socrates' soul since his early years and the voice would dissuade him from some activities. It was a prophetic voice: “The internal voice does not reveal to him any truth, it does not give him any supernatural light; it is just a brake, that does not allow him to do certain things. The philosopher considered it to be the voice of God, under whose particular guidance he believed he was, and a Christian sees nothing exceptional in it. After all, every soul, in different degrees and forms, receives similar inspirations from the above, so no proof against rationalism is required here. For a historian it is enough that Socrates was convinced of it and obeyed it in his life. The particular kind of such inspirations is irrelevant to philosophy, for it does not affect it in any respect" (Pawlicki 1890: 390). In other words, it was particularly important for Pawlicki that the voice of God, or the Revelation did not speak to Socrates. Socrates had certain intuitions, and there is nothing exceptional about them. They might even accord with the Gospel. Nevertheless, Socrates was certainly not given any divine inspiration that is characteristic of Christian writers exclusively. Socrates does not count among them. As Pawlicki (1890: 394) puts it: "Socrates is probably very far from Christ's commandment: »Love your enemies, do good to those who hate you, bless those who curse you, pray for those who abuse you «, but the bridge is thrown, and over the bridge humankind will walk from the birch of envy to the olive branch of the brotherhood of the nations. The Athenian sage did not say: »love your enemies «, he only forbade it that any harm be done to them. Yet, this prohibition, even if expressed only in a negative form, was an enormous progress in comparison to the persecution that the distorted conscience of the then peoples demanded".

Aside from the Catholic interpreters, an important part in the reception of the Euthyphro was also played by various gymnasium teachers. This can be clearly seen from the yearly gymnasium reports. Two such works will be presented here: the papers by Andrzej S. Jezierski (ca. 1860-1894) and Jan Tralka (1857-1916). The former taught in various schools in Lwów, Nowy Sącz, Tarnów and Tarnopol, whereas the latter taught in Stryj. The works of classicists on ancient philosophy focused usually on one author or text. 
Most of such studies were published in Polish (sometimes in Latin), and their purpose was to explain specific philological, literary and philosophical issues. Although their goal was first and foremost didactic, they were often reviewed in professional journals.

Tralka's paper is quite typical of this genre. In its introduction, the reader could find some basic information concerning the history of Greece and the genesis of Sophistry that were to provoke Socrates to defy the Sophists' relativism. After a short presentation of the general aims and subjects of other Socratic dialogues (Protagoras, Euthydemos, Laches, Gorgias), Tralka went on to count the Euthyphro among the transitory dialogues, arguing that Plato wrote them undoubtedly under Socratic influence, even though his original aim was already discernible, He characterized the aim as "the urge to lay the foundations of his philosophical dialectic; Plato could not have been satisfied with the negative aim of merely demonstrating the fallaciousness of the Sophists' views; rather, he intended to replace the theories he had criticized with the new ones that were based on the rules of strict logical reasoning, producing, thus, his own system" (Tralka 1897: 4).

Plato was the first to have developed a philosophical method, for "he provided the rules stipulating the concept formation" (Tralka 1897: 4). Socrates consciously made use of them in the following way: "after launching into a dispute with somebody, he attempted to set the wrong concept right by way of inductive reasoning, and through this, to direct his interlocutor's thought from false premises onto the right ones" (Tralka 1897: 4). Along with other Socratic dialogues, the Euthyphro was an excellent example of such an approach.

Jezierski, on the other hand, started his paper on the Euthyphro by presenting the dramatis personae and the general setting of the dialogue. According to Jezierski (189o: 4), Euthyphro exemplifies "a good-hearted, irreproachable and righteous way of thinking" - and this must have been the only reason that made Socrates talk to him. "On the other hand, this was also a shallow mind that was totally incapable of any logical thinking or scientific investigation" (Jezierski 1890: 4). Usurping knowledge of divine matters, "he proves to be very conceited because of his alleged art" (Jezierski 1890: 5). This reflects a serious misunderstanding of the nature of the gods: "it is on the basis of folk beliefs that the shallow and erroneous mind of Euthyphro stands" (Jezierski 1890: 5). When interpreting the dialogue, Tralka (1897: 5) also severely criticized Socrates' interlocutor: "It is a shallow, empty mind that is incapable of any philosophical reasoning; he is dull and unnatural in action".

The glaring contrast between Socrates and Euthyphro was perfectly suited for different didactic purposes. The former "has knowledge of real piety, is familiar with the rules of logical thinking, and possesses extraordinary intellectual resourcefulness, but he conceals his superiority over the effusive religious fanatic, who is incapable of any scientific discussion" (Jezierski 1890: 7). Furthermore, Euthyphro's fanaticism "following the line of the Sophists was calculated to gain admiration and blaze of sanctity for himself" (Jezierski 1890: 6). Students could thus easily see the difference between the superficial piety of Euthyphro and the deep piety of Socrates. "The conversation on piety conducted by the two characters shows Socrates as a representative of real piety that is based on a deep understanding of its essence and meaning which manifests itself in a truly virtuous 
life. Euthyphro, on the other hand is a priest-Sophist that represents an apparent piety which is based on folk superstition only and is not confirmed by any internal godliness" (Jezierski 1890: 7). For didactic purposes, Jezierski presented the conversation between Socrates and Euthyphro in clauses, summarizing, thus, the most important passages of the dialogue: attempts at defining piety, their refutation, and Socrates' criticism of the petitio principii error.

On the basis of its construction, Tralka counted the Euthyphro among the polemical dialogues leveled against the Sophists, noting, though, the absence of direct criticism of Sophistry. His argument had it that as the subject of the dialogue, i.e. the definition of piety, arose from Meletos' accusation of Socrates, it would have been reasonable to make the accuser Socrates' opponent in the dialogue. Tralka (1897: 13) explained that Plato did not do for the following reason: "Wanting to save the humorous tenor, full of irony and scorn, that are typical of Socrates in his conversations with Sophists, Plato selected Euthyphro as the conversation character, and not for instance Meletos, who was an ignoramus, incapable of comprehending anything. Thus, he made it easier to prove to Euthyphro, who boasted about his authority in divine matters, that his concept of religion was based on false assumptions". In this respect, the dialogue could be regarded as a sui generis introduction to the Apology. An interesting feature of Tralka's and Jezierski's papers, this being dictated by the didactic purposes of their works, was the narration in Polish interspersed with Greek words and phrases. The authors did not explain any, assuming that the student would be familiar with them.

Let us turn to the texts themselves: "Euthyphro says that he could tell him more horrifying stories of that kind, should he want that. Socrates, however, postponing this for some other free moment (غ่лì $\sigma \chi 0 \lambda \tilde{\eta} \varsigma$ ), draws Euthyphro's attention back to their current preoccupation, i.e. that he has not taught him what piety is, but merely stated

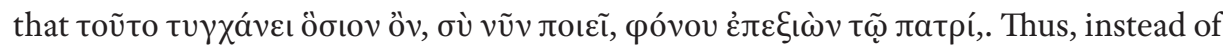
a definition of piety, he gave just one example of toũ óoíov, whereas there are many other examples which elude such concept of piety" (Jezierski 1890: 4). In Tralka's work, on the other hand, one may read the following: "Seeing Euthyphro's confusion, Socrates releases

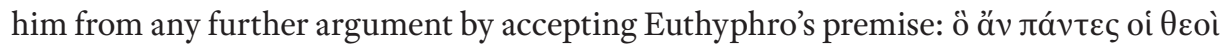
$\varphi \iota \lambda \tilde{\omega} \sigma ı v$ etc. However, he immediately says that the issue needs closer examination, for Euthyphro's premise may have two alternatives, that a) tò ô

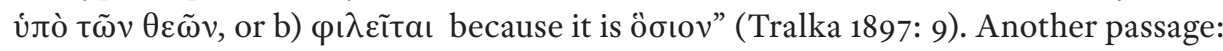
"Socrates, observing that his interlocutor is falling behind in thinking, assumes the role of a teacher. He explains to Euthyphro that when defining a given concept, one must first accept some genus proximum. Then, he gives such a premise and asks Euthyphro whether he thinks that tò ô widen the content of the concept and reduce its scope with differentia specifica, with the feature which distinguishes the concept in question from the similar one" (Tralka 1897: 10).

Jezierski (1890: 24) recognized a twofold purpose in the dialogue: "In the first half of the conversation [there is a lot of] Socratic polemic against the indecent and perverse views about the gods and religion that Euthyphro, a fanatic priest representing the Athe- 
nian people, exhibits. At the same time, Socrates, having been just accused of heathenism, also presents his defence. In the second half of the dialogue, there is an intention to dialectically define the concept of piety". According to Jezierski, Plato in the Euthyphro stresses the rationalism of Socrates. This is not, however, such a rationalism that only leads to abstract ideas, but it is always closely connected to ethical issues: "considering various manifestations of external life goes never by without some benefit for pure philosophy; and, conversely, even in purely dialectical dialogues we also find hints at how to conduct our lives" (Jezierski 1890: 24). A similar point has been made by Tralka. Although Socrates is unable to produce any definition of piety with Euthyphro's help, the reader may, nevertheless learn of the Socratic-Platonic concept of piety on the basis of the difference between the two interlocutors' views. Socrates's hints and guidance are very helpful in this matter. For these reasons the dialogue was regarded by Tralka as an instructive, and not merely polemical, dialogue. Furthermore, the reader can also learn to identify the logical errors concerning the definition and scope of concepts. Tralka (1897: 11) stated: "this work clarifies the dialectical method of Socrates, who demanded

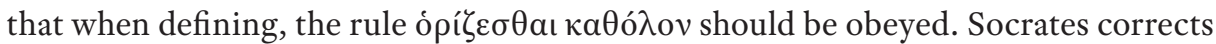
erroneous concepts and ideas, he rejects those that are ambiguous or unclear, and deletes the logical errors." The scholar regarded the dialogue as the most mature in the first period of Plato's literary production: "it is a transitional writing that leads to the second, i.e. dialectical phase of Plato's writings" (Tralka 1897: 18).

Neither Jezierski nor Tralka was content with the Euthyphro alone. The former made the dialogue a starting point for a discussion concerning the concept of piety in all other dialogues. The latter undertook a closer examination of the theory of ideas. The final parts of their works are the most original and bear testimony to their interest in philosophy. Jezierski argued that the Euthyphro is the source of all later Platonic ethical concepts presented in other dialogues. According to the scholar, this confirmed its authenticity. As Plato's last definition of piety, Jezierski (1890: 40) quoted the Laws, where: "Piety [...] consists in the creature's absolute devotion to the deity, as an instrument for carrying out the divine will which demands that man get rid of any unchaste lusts and by practicing virtue rise to the source of all the good". Jezierski concluded his works with a discussion on the Euthyphro's authenticity. He did not decide whether the conversation, in the form as it is presented in the dialogue, actually took place. He also noticed the difficulties connected with determining the exact date of the dialogue, although he had no doubts about its early character, this being evidenced by its simplicity and the modesty of the scenery. On the other hand, Jezierski (1890: 43) emphasized that this might also have been an intentional device provoked by the subject of the dialogue, i.e. piety: "he clothed it in a modest robe, which suited it best because of its nature". After Socrates' death Plato left for Megara and “with his writings he attempted to open the Athenians' eyes to the crime they had committed by sentencing an innocent man to death"(Jezierski 1890: 46). Nevertheless, Jezierski did not want to rule out the hypothesis that the Euthyphro was written long after Socrates' death. In favor of this hypothesis, Jezierski cited some philosophical arguments. In Xenophon's and Plato's early dialogues, justice and piety 
were equal virtues, the relation of one man to another being the subject of the former and the relation of a man to the deity being the subject of the latter. In the Euthyphro (12 e), however, Socrates asked the question that concerned justice as a part of piety. Adducing the arguments from the theory of ideas, Jezierski concluded that the Euthyphro was thought over and written as the last Socratic dialogue, i.e. as a transition to the dialectical period. Thus, he argued, it must have been written in Megara.

On the basis of various German works, Tralka attempted to present "the so-called Platonic ideology". Its first stage was an inductive search for a definition of an ethical concept. Tralka, like Jezierski, was an adherent of the theory that Plato stayed in Megara after Socrates's death. Plato broadened his philosophical interests there and went beyond the ethical issues. Then, contrary to the Sophists, he assumed that objective knowledge was possible, and, finally, in the last stage of his literary activity, Plato sought to create a philosophical system. To sum up, there are three stages of Plato's evolution: 1) the Socratic-ethical period with its increasing interest in logic, the Euthyphro belonging to this period; 2) the "ideological" period with the prevalence of metaphysical interests; 3) the systematic period. Such a vision of Plato's philosophical evolution was based on the chronology of the dialogues. While assuming that the Phaedrus was a mature dialogue, the scholar also considered the Sophist and Parmenides to belong to the second period, followed by the Phaedrus, Symposium, Phaedo, Philebus and Timaeus.

Finally, Wincenty Lutosławski (1863-1954) will also be mentioned here. In his classification, the Euthyphro is one of the earliest dialogues. The stylistic affinity of the dialogue with the Laws was, according to Lutosławski's method of stylometry, counted as 0.03 to 1.o. By way of comparison, the dialogue was classified as the earliest. The Apology bore a smaller number, i.e. 0.02 (Lutosławski 1897: 163). The Euthyphro, Crito and Apology were written, according to Lutosławski, soon after Socrates' death. And Plato's stay in Megara did not result in the composition of any of the dialogues, let alone any of the dialectical dialogues. This was claimed against the common opinion held by the scholars in the $19^{\text {th }}$ century.

This most eminent Polish Plato scholar, whose investigations have been widely read and commented on, considered the period of direct Socratic influences to be the first stage of Plato's philosophical development. The dialogues of this period are short and focus on ethical issues. The most important character is clearly Socrates, who dominates his interlocutors. In the ethical issues the emphasis is put on defining certain ethical concepts or refuting the Sophists. Lutosławski regarded the Euthyphro as very significant for Plato's philosophical development.

Some distinctively Socratic features are found in the Euthyphro, these resulting from the Socratic influences and the absence of original Platonic considerations. One of those features is a frequent use of analogy and induction in order to formulate a definition of a given concept. Another important feature is emphasis on the insufficiency of a simple enumeration for definition. Socrates attempts to grasp a certain characteristic feature, a differentia specifica of the concept under examination, he calls it íf́a, without, however, any metaphysical sense. The other term, typical of Plato's later metaphysical vocabulary 
is ларá $\delta \varepsilon \imath \mu \mu$. Likewise, its meaning in the Euthyphro is limited to the common use (Lutosławski 1897: 188-200). There is, however, one substantially Platonic remark in the dialogue. Plato distinguished between a primary action and a secondary state resulting from the action: "any state of action or passion implies previous action or passion. It does not become because it is becoming, but it is in a state of becoming because it

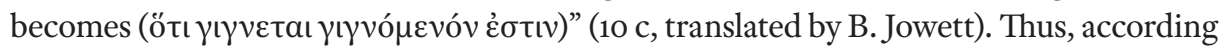
to Lutosławski, the Euthyphro, has to be counted among Plato's early dialogues on both philosophical and philological grounds.

Most of the issues concerning the Euthyphro pertain also to other Socratic dialogues. The Apology was also one of the dialogues that was frequently read by various Christian thinkers. The questions of chronology was of secondary importance for them. The dialogue provided convenient and diverse material for the Greek language classes or preparatory courses in philosophy or logic. The teachers' works on the Euthyphro which were published in the gymnasiums' annual reports are typical of this genre. They were composed by experienced teachers and they intended to present the comprehensive interpretation of the examined text. Various scholars offered some attention to the issue of ordering the dialogues, but they were profoundly influenced by German scholarship. Examining the authenticity of Socrates' picture in the Euthyphro was rare. Generally, it was accepted that the Platonic Socrates from the early dialogues was identical with the so-called historical Socrates. 


\section{BIBLIOGRAPHY:}

ADAmsкi J., 1883/1884, „Euthyfron, pierwszy dialog Platona, rozebrany i oceniony w zastosowaniu do nowego ruchu myśli”, Warta 11, fasc. 483-486, 488, pp. 4577-4578, 4585-4587, 4593-4594, 4604-4606, 4617-4619.

JeZIERski A. S., 1890, „Eutyfron” czyli o pobożności, Tarnopol.

JeżEwska K., 1957, „Słowo od wydawcy”, in: Platon, Uczta, translated by W. Witwicki, Warszawa, pp. 5-8.

LutosŁaWski W., 1897, The Origin and Growth of Plato's Logic with an Account of Plato's Style and of the Chronology of His Writings, London - New York - Bombay.

Pawlicki S., 1890, Historya filozofii greckiej od Talesa do Platona, vol. I, Kraków.

Platon, 1858, Dzieła, vol. 1, translated by A. Bronikowski, Poznań, pp. 247-272.

Platon, 1881, Protagoras, Eutyfron, translated by S. Siedlecki, Kraków, pp. 83-106.

Tralka J., 1897, Osnowa, uktad i cel Platońskiego Eutyfrona. Istota idei, Stryj.

TOMASZ MRÓZ

/Zielona Góra /

K EY WOR D S

\section{Some Remarks on the Nineteenth Century Studies of the Euthyphro in Poland}

The present paper examined how Polish philosophers, historians and classicists understood and interpreted Plato's Euthyphro in the $19^{\text {th }}$ century. The article provides evidence for a twofold interest that Polish readers had for the dialogue in this period. Firstly, Catholic thinkers focused on the ethical issues of the dialogue and supported the revival of the Scholasticism, confirming, at the same time, the vitality of Plato's thought. Secondly, the text of Plato's opusculum was a convenient didactic material for various teachers of the Greek language: while the Euthyphro gave them the opportunity to raise ethical and logical issues, they also taught philosophy on the basis of this dialogue.

Plato, Euthyphro, Adamski, Jezierski, Lutosławski, Pawlicki, Tralka 